\title{
PERSEPSI GURU TERHADAP PENILAIAN HIGHER ORDER THINKING SKILLS (HOTS) (Studi pada UPT Satuan Pendidikan SMAN 1 Jeneponto)
}

\author{
Oleh: \\ ANUGRAH SUKMAWATI ${ }^{1}$, HASNAWI HARIS ${ }^{2}$, MUSTARI ${ }^{3}$ \\ Fakultas Ilmu Sosial, Universitas Negeri Makassar \\ e-mail: 1anugrahsukmawati2@gmail.com, ${ }^{2}$ hasnawi.haris@unm.ac.id, \\ ${ }^{3}$ mustari6508@unm.ac.id
}

\begin{abstract}
ABSTRAK: Persepsi Guru Terhadap Penilaian Higher Order Thinking Skill (HOTS) (Studi Pada UPT Satuan Pendidikan SMAN 1 Jeneponto). Skripsi Jurusan Pendidikan Pancasila dan Kewarganegaraan Fakultas Ilmu Sosial Universitas Negeri Makassar. Dibimbing oleh Mustari dan Hasnawi Haris. Penelitian ini bertujuan untuk mengetahui: (1) Pengetahuan guru UPT Satuan Pendidikan SMAN 1 Jeneponto terhadap penilaian Higher Order Thinking Skills (HOTS); (2) Sikap guru UPT Satuan Pendidikan SMAN 1 Jeneponto terhadap penilaian Higher Order Thinking Skills (HOTS). Penelitian ini menggunakan jenis penelitian kualitatif dan menggunakan pendekatan penelitian deskriptif kualitatif. Berdasarkan sumbernya, jenis data yang digunakan yaitu data primer dan data sekunder. Data primer diperoleh melalui metode wawancara terhadap guru aktif pada UPT Satuan Pendidikan SMAN 1 Jeneponto. Sedangkan data sekunder yaitu data yang diperoleh dari berbagai literatur seperti buku dan undang-undang maupun sumber lain yang berkaitan. Pengolahan data dan penyajian data dilakukan secara deskriptif.Hasil penelitan menunjukkan bahwa: 1) Guru UPT Satuan Pendidikan SMAN 1 Jeneponto belum mengetahui dengan baik mengenai penilaian Higher Order Thinking Skills (HOTS), terlihat dari pengetahuannya mengenai peraturan terkait penerapan penilaian HOTS, karakteristik penilaian HOTS, dan langkah-langkah penyusunan soal HOTS. 2) Persepsi guru UPT Satuan Pendidikan SMAN 1 Jeneponto terbagi atas dua aspek sikap, yaitu: (1) Sikap setuju guru terhadap penerapan penilaian HOTS (2) Sikap tidak setuju guru terhadap penerapan penilaian HOTS.
\end{abstract}

\section{KATA KUNCI: Persepsi Guru, Penilaian HOTS}

ABSTRACT: Teacher's Perception of Higher Order Thinking Skill (HOTS) Assessment (Study at UPT Education Unit of SMAN 1 Jeneponto). Thesis Department of Pancasila and Citizenship Education Faculty of Social Sciences, Makassar State University. Supervised by Mustari and Hasnawi Haris. This study aims to find out: (1) The knowledge of UPT teachers at Jeneponto Senior High School Education Unit on the assessment of Higher Order Thinking Skills (HOTS); (2) The attitudes of UPT teachers at the 1 stepepenece of SMAN 1 Jeneponto towards the Higher Order Thinking Skills (HOTS) assessment. This study uses a qualitative research type and uses a qualitative descriptive research approach. Based on the source, the type of data used is primary data and secondary data. Primary data were obtained through interviews with active teachers at the UPT Education Unit of SMAN 1 Jeneponto. Whereas secondary data is data obtained from various literatures such as books and laws and other related sources. Data processing and data presentation are done descriptively. Research results show that: 1) Teachers of UPT Education Unit of SMAN 1 Jeneponto do not know well about the assessment of Higher Order Thinking Skills (HOTS), it can be seen from their knowledge of the 
regulations regarding the application of HOTS assessment, HOTS assessment characteristics, and steps for preparing the HOTS question. 2) The perception of UPT teacher at SMAN 1 Jeneponto Education Unit is divided into two aspects of attitude, namely: (1) The teacher's agreed attitude towards the application of the HOTS assessment (2) The attitude of the teacher's disapproval of the application of the HOTS assessment.

KEY WORDS: Teacher's Perception, HOTS Assessment

\section{PENDAHULUAN}

Pendidikan merupakan hal yang urgen dan strategis dalam rangka pengembangan kemampuan manusia dalam berbagai aspek. Melalui pendidikan manusia diharapkan mampu menjadi manusia seutuhnya yang mempunyai keterampilan, kemampuan, serta mempunyai daya saing dalam menghadapi era millenium dan revolusi industri 4.0. Oleh sebab itu hampir semua negara menempatkan variabel pendidikan sebagai salah satu yang penting dan utama dalam konteks pembangunan bangsa dan negara, termasuk di Indonesia yang juga menempatkan pendidikan sebagai prioritas utama dalam program pembangunan nasional.

Kurikulum merupakan salah satu komponen penting dalam pendidikan. Kurikulum 2013 merupakan kurukulum yang berlaku secara Nasional di Indonesia. Seiring dengan implementasinya, kurikulum 2013 saat ini mengalami penyempuranaan pada standar isi dan standar penilaian. Pada standar isi dirancang agar peserta didik mampu berpikir kritis dan analitis sesuai dengan standar internasional dengan melakukan pengurangan materi yang tidak relevan dan pendalaman serta perluasan materi yang relevan bagi peserta didik. Sedangkan pada standar penilaian dilakukan dengan mengadaptasi model-model penilaian standar internasional secara bertahap. Penilaian hasil belajar lebih menitik beratkanpada kemampuan berpikir tingkat tinggi (Higher Order Thinking Skills/HOTS $)^{1}$

Higher Order Thinking Skills merupakan suatu keahlian menggabungkan, memanipulasi, dan mentransformasi pengetahuan serta pengalaman yang sudah dimiliki untuk berfikir kritis dan kreatif dalam menentukan keputusan dan memecahkan masalah pada situasi baru. Berpikir kritis merupakan kemampuan proses mental individu yang diperoleh melalui pengalaman, sehingga individu dapat membuat keputusan atau tindakan yang baik. Berpikir kreatif yaitu keahlian untuk menggunakan pola berpikir yang rumit sehingga memunculkan pemikiran baru dan orisinil.

Upaya meningkatkan kemampuan berpikir tingkat tinggi peserta didik juga diterapkan berdasarkan data yang menyatakan bahwa pada umumnya kemampuan peserta didik Indonesia dalam memahami informasi yang kompleks, teori, analisis, pemecahan masalah, pemakaian alat, prosedur dan melakukan investigasi sangat rendah. Data tersebut berdasarkan hasil studi Internasional Programme for Internasional Student Assessment (PISA) bahwa prestasi literasi membaca (reading literacy), literasi matematika (mathematical literacy), dan literasi sains (scientific literacy) peserta didik Indonesia sangat rendah. Maka dari itu diperlukan adanya perubahan sistem

\footnotetext{
${ }^{1}$ Kemendikbud 2017
} 
dalam pembelajaran dan penilaian yang berorientasi HOTS. ${ }^{2}$

Selain itu data selanjutnya berdasarkan pada karakteristik skills masyarakat abad ke-21 yang dipublikasikan oleh Partnership of $21^{\text {st }}$ Century Skill mengidentifikasikan bahwa pebelajar pada abad ke-21 harus mampu mengembangkan keterampilan kompetitif yang diperlukan pada abad ke21 yang berfokus pada pengembangan Higher Order Thinking Skills, seperti : berpikir kritis (critical thinking), pemecahan masalah (problem solving), keterampilan berkomunikasi (communication skills), melek TIK, tekhnologi informasi dan komunikasi (ICT/ Information and Communication Technology), melek informasi (information literacy), dan melek media (media literacy). ${ }^{3}$

Guru menjadi garda terdepan dalam penyelenggaraan pendidikan di Indonesia. Guru adalah individu yang berhadapan langsung dengan peserta didik di kelas. Oleh karena itu, agar peserta didik dapat mengembangkan penilaian HOTS, maka guru harus memiliki kemampuan dalam membiasakan pembelajaran maupun pemberian soal-soal yang memuat HOTS terhadap peserta didik ketika mengadakan suatu tes/ujian seperti ulangan harian, ulangan tengah semester, d an ulangan akhir semester. Kemampuan guru dalam melaksanakan tugasnya tercermin dari kompetensi yang harus dimilikinya. Hal tersebut sudah tercantum dalam UU Nomor 14 tahun 2005 tentang Guru dan Dosen "Terdapat empat kompetensi minimal yang harus dimiliki oleh seorang guru yaitu kompetensi

\footnotetext{
${ }^{2}$ Kemendikbud 2016

${ }^{3}$ Emi Rofiah, dkk. 2013.Penyusunan Instrumen Tes Kemampuan Berpikir Tingkat Tinggi Fisika pada Siswa SMP. Jurnal Pendidikan Fisika. 1.2, hlm. 17-22.
}

pedagogik, kepribadian, sosial, dan profesional.".4

Dalam melaksanakan penilaian HOTS berkaitan dengan kompetensi pedagogik yang dimilikinya. Kompetensi ini berkaitan dengan kemampuan guru dalam merancang, mengimplementasikan, serta mengevaluasi pembelajaran. Kompetensi ini terdiri dari pemahaman wawasan atau landasan kependidikan, pemahaman terhadap peserta didik, pengembangan kurikulum, pengembangan silabus, perancangan pembelajaran, pelaksanaan pembelajaran yang mendidik dan dialogis, pemanfaatan teknologi pembelajaran, evaluasi hasil belajar, dan pengembangan peserta didik untuk mengaktualisasikan berbagai potensi yang dimilikinya. $^{5}$

Berkaitan dengan kompetensi guru angka indeks pembangunan manusia (IPM) dari United Nations Development Programme (UNDP), Indonesia hanya meraih 0,689 dan berada di peringkat ke113 dari 188 negara. Begitu pula UNESCO dalam Global Education Monitoring (GEM), menempatkan pendidikan di Indonesia berada peringkat ke-10 dari 14 negara berkembang. Sementara itu, komponen guru menempati urutan ke-14 dari 14 negara berkembang di dunia. Hingga di sini, mungkin ada masalah dengan kompetensi guru. Potret kualitas guru di Indonesia juga tercermin dalam Uji Kompetensi Guru (UKG) nasional tahun 2018 yang diikuti oleh lebih dari 2,9 juta guru menghasilkan rata-rata di bawah angka 70 berada jauh dibawah nilai standar $100{ }^{6}$

Guru profesional sangat diperlukan dalam merespon dan menindak lanjuti berbagai pembaharuan, termasuk penilaian HOTS yang terbilang

\footnotetext{
${ }^{4}$ UU RI Nomor 14 tahun 2005 tentang Guru dan

Dosen

${ }^{5}$ Ibid.

${ }^{6}$ Kemendikbud 2017
} 
baru melalui pendampingan pemerintah dalam memperkenalkan keterampilan HOTS tersebut sehingga dapat mencapai tujuan yang diinginkan yaitu peningkatan kualitas mutu pendidikan. Untuk sampai pada tujuan yang diinginkan guru memerlukan jembatan berupa pengetahuan dan pemahaman cukup terkait penilaian HOTS, namun berdasarkan data tersebut diatas belum terlihat peningkatan keterampilan peserta didik Indonesia dalam mengerjakan soal HOTS sejak awal penerapannya pada tahun 2016. Melihat fenomena tersebut, penulis tertarik melakukan penelitian dengan mengangkat judul "Persepsi Guru terhadap Penilaian Higher Order Thinking Skills (HOTS) (Studi Pada UPT Satuan PendidikanSMAN 1 Jeneponto)"

\section{METODE PENELITIAN}

Penelitian ini menggunakan
pendekatan kualitatif yaitu suatu
pendekatan penelitian yang
menghasilkan data deskriptif berupa data
tertulis maupun lisan dari orang-orang
dan perilaku yang dapat diamati.
Jenis penelitian yang digunakan
dalam penelitian ini, yaitu penelitian
kualitatif dimana penelitian ini
menekankan pada deskripsi atas
fenomena yang diteliti yang mempunyai
tujuan untuk mendeskripsikan,
menjelaskan, dan menggali informasi
mengenai Persepsi Guru Terhadap
Penilaian Higher Order Thinking Skills
(HOTS) Studi pada UPT SMAN 1
Jeneponto.

Penelitian ini berlokasi di UPTD

SMA Negeri 1 Jeneponto Provinsi Sulawesi Selatan Kecamatan Binamu Kabupaten jeneponto, tepatnya di Jalan Pendidikan Nomor 50, Telepon (0419) 21257, Kode Pos 92316. Sekolah ini resmi beroperasi pada tanggal 10 Mei 1961 dan merupakan SLTA tertua di Kabupaten Jeneponto. Gedung yang dimiliki sekolah ini terdiri dari 36 ruang kelas, 2 ruang laboratorium IPA, 1 ruang laboratorium Komputer, 1 ruang laboratorium Bahasa, 1 ruang perpustakan, dan dilengkapi oleh fasilitas lainnya. Jumlah peserta didik UPTD SMAN 1 Jeneponto pada tahun ajaran 2019/2020 sebanyak 761 peserta didik, dengan perincian 338 laki-laki dan 423 perempuan, dengan tenaga pendidik berjumlah 55 guru, 1 kepala sekolah, dan beberapa orang staf tenaga kependidikan. Deskripsi fokus penelitan ini adalah persepsi guru UPT Satuan Pendidikan SMAN 1 Jeneponto. Persepsi yang dimaksud adalah: (1) Pandangan atau penafsiran guru terhadap apa yang diketahui, dilihat, didengar, dan dirasakan terhadap penerapan penilaian HOTS pada aspek persepsi yakni pengetahuan yang terdiri atas mengetahui adanya peraturan tentang penilaian HOTS, mengetahui karakteristik penilaian HOTS, mengetahui langkahlangkah dalam menysun soal HOTS. (2) Pernyataan sikap guru UPT Satuan Pendidikan SMAN 1 Jeneponto dalam mengambil keputusan setuju atau tidak setuju terhadap penerapan penilaian HOTS.

Ada tiga tahap dalam penelitian ini yaitu tahap perencanaan, pelaksanaan, dan laporan penelitian. (1) Tahap Perencanaan; Tahap perencanaan merupakan tahap pertama yang dilakukan oleh peneliti yang meliputi: (a) Mengidentifikasi masalah, Merumuskan masalah yang akan diteliti, (c) mengadakan studi pendahuluan. (d) Menyusun rencana penelitian. (2) Tahap Pelaksanaan Penelitian: (a) Pengumpulan data atau informasi yang terkait dengan fokus penelitan, (b) analisis data yang dilakukan setelah data terkumpul. (3) Tahap Penulisan Laporan hasil Penelitian. Pada tahap ini hasil penelitian akan dilaporkan dalam bentuk skripsi. Tahap laporan penelitian ini merupakan 
tahap akhir dalam sebuah proses penelitian.

Terdapat 2 (dua) jenis data yang digunakan dalam penilaian ini yaitu data primer dan data sekunder. Sumber data primer dalam penelitian ini adalah data yang diperoleh secara langsung melalui observasi dilapangan serta wawancara dengan informan berkaitan dengan penelitian di lokasi penelitian. Adapun informan yang dipilih adalah orang-orang yang terlibat langsung serta memahami dan dapat memberikan informasi yang berkaitan dengan penelitian ini guru aktif UPTD SMAN 1 Jeneponto yaitu sebanyak 10 orang. Sumber data sekunder dalam penelitian ini adalah data yang diperoleh melalui buku-buku ilmiah, jurnal, hasil penelitian ataupun makalah seminar, data dari internet, dan hasil wawancara dengan narasumber.

Instrumen penelitian menurut Nasution merupakan alat bantu bagi peneliti dalam mengumpulkan data. Instrumen yang digunakan peneliti adalah instrumen pokok dan instrumen penunjang. Instrumen pokok adalah peneliti itu sendiri sedangkan instrumen penunjang adalah berupa pedoman wawancara, alat rekam, kamera, dan buku catatan .

Prosedur Pengumpulan Data. (1) Metode Observasi; metode pengumpulan data yang dilakukan secara tersistematis yang meliputi pengamatan dan pencatatan gejala yang terjadi. Metode observasi yang digunakan dalam penelitian ini yaitu Observasi NonPartisipan. (2) Metode wawancara yang digunakan untuk memperoleh data primer dengan mengadakan tanya jawab dengan pihak-pihak yang bersangkutan dengan masalah yang sedang diteliti, adapun metode wawancara yang digunakan dalam penelitian ini terdiri atas: (a)

\footnotetext{
${ }^{7}$ Sugiono, 2013. Metode Penelitian Pendidikan. Cetakan ke-16. Bandung: CV ALVABETA, hal.306
}

Wawancara terstruktur adalah sebuah metode wawancara yang dilaksanakan secara terencana dengan berpedoman pada daftar pertanyaan yang telah dipersiapkan sebelumnya. (b) Wawancara tidak terstruktur adalah sebuah metode wawacara yang tidak berpedoman pada daftar pertanyaan tertentu dan dilaksanakan secara aksidental tanpa melalui tahap perencanaan sebelumnya (3) Metode Dokumentasi; pengambilan data yang diperoleh melalui dokumen, dalam bentuk catatan-catatan, rekaman suara, transkrip, foto, dan sebagainya.

Pada penelitian ini teknik pengecekan keabsahan data menggunakan Triangulasi Data dilakukan dengan tujuan untuk membandingkan data yang diperoleh dari data yang berupa observasi dan wawancara. Triangulasi yang digunakan dalam penelitian ini adalah triangulasi waktu untuk mengecek kembali keabsahan data yang didapatkan di lokasi penelitian pada orang yang sama dengan waktu yang berbeda.

Teknik analisis data menurut Patton merupakan proses mengatur urutan data, mengorganisasikannya ke dalam suatu pola, kategorisasi, dan satuan uraian dasar. Sedangkan menurut Bogdan analisis adalah proses mencari dan menyusun secara sistematis data yang diperoleh dari hasil wawancara, catatan lapangan, dan bahan bahan lain, sehingga dapat mudah dipahami, dan temuannya dapat diinformasikan kepada orang lain. ${ }^{8}$ Teknik analisis data yang digunakan dalam penelitian ini adalah mengacu pada konsep Milles \& Hubberman yaitu Interactive model yang mengklasifikasikan analisis data dalam 3 langkah, yaitu: (1) Reduksi Data (Data Reduction); Reduksi data yaitu suatu

${ }^{8}$ Ibid, hal. 334 
proses pemilahan, pemusatan perhatian pada penyederhanaan, pengabstakan dan transformasi data kasar yang muncul dari catatan-catatan tertulis dilapangan. (2) Penyajian Data (Display Data), data tersusun sedemikian rupa sehingga memberikan kemungkinan adanya penarikan kesimpulan dan pengambilan tindakan. Adapun bentuk yang lazim diguanakan pada data kualitatif terlebih dahulu adalah dalam bentuk teks naratif. (3) Penarikan Kesimpulan (Verifikasi); mengungkap mengenai makna dari data yang dikumpulkan. Dari data tersebut akan diperoleh kesimpulan yang tentatif, kabur, kaku dan meragukan, sehingga kesimpulan tersebut perlu diverifikasi. Verifikasi dilakukan dengan melihat kembali reduksi data maupun display data sehingga kesimpulan yang diambil tidak menyimpang. ${ }^{9}$

\section{HASIL DAN PEMBAHASAN}

Evaluasi dalam pembelajaran merupakan proses yang dilaksanakan oleh guru untuk mengetahui sejauh mana peserta didik mencapai tujuan pembelajaran yang telah ditetapkan sebelumnya. Berkaitan dengan hal tersebut pemerintah telah menerapkan kebijakan dalam Peraturan Menteri Pendidikan dan Kebudayaan Nomor 20 tahun 2016 tentang standar kompetensi lulusan pendidikan dasar dan menengah yang menghendaki pengembangan pembelajaran dan penilaian yang berorientasi Higher Order Thinking Skills (HOTS) yang bertujuan untuk meningkatkan kualitas pembelajaran dan meningkatkan kualitas lulusan. Kesuksesan dari penerapan penilaian HOTS ini sangat bergantung pada peran guru sebagai pendidik profesional. Pada kenyataannya guru tidak begitu saja dapat langsung menguasai setiap kebijakan pemerintah, termasuk penilaian HOTS yang telah menuai pro dan kontra dikalangan guru.

Guru pada masa ini dapat mengakses informasi terkait penilaian HOTS melalui kegiatan sosialisasi, seminar pendidikan, buku, forum guru, rapat guru, pelatihan guru yang diselenggarakan oleh pemerintah, dan media sosial. Pemerintah telah mengunggah Buku Penilaian Berorientasi Higher Order Thinking Skills yang dapat di unduh melalui laman web resmi Kementerian Pendidikan dan Kebudayaan. Wawasan guru terhadap penilaian HOTS akan mempengaruhi optimalnya penerapan penilaian HOTS terhadap peserta didik. Kemudahan dalam mengakses informasi serta memperoleh pelatihan penilaian HOTS akan memberi jalan kepada guru untuk mengetahui, memahami, serta menyikapinya. Begitupun dengan guru pada UPT Satuan Pendidikan SMAN 1 Jeneponto yang menjadi sasaran peneliti untuk melaksanakan penelitian terkait pro-kontra penilaian Higher Order Thinking Skills atau penilaian berorientasi pada kemampuan berpikir tingkat tinggi.

Penelitian yang dilakukan di UPT

Satuan Pendidikan SMAN 1 Jeneponto pada tanggal 24 Juni sampai 24 Juli 2019 menggunakan metode wawancara terhadap guru UPT Satuan Pendidikan SMAN 1 Jeneponto yang masih aktif mengajar, terdiri dari 10 guru mata pelajaran Matematika, Olahraga, PKN, Bahasa Inggris, Pendidikan Agama Islam, Sejarah Indonesia, dan Kimia. Sehingga dalam melaksanakan penelitian, peneliti mewawancarai guru berdasarkan pada pedoman wawancara yang telah disusun sebelumnya. Wawancara dilakukan hingga penulis memperoleh hasil yang dibutuhkan. Indikator memilih informan ialah guru

\footnotetext{
${ }^{9}$ Ibid, hal. 337-345
} 
yang telah aktif mengajar sebelum tahun 2016 atau sebelum diterapkan penilaian HOTS.

Berdasarkan hasil wawancara, peneliti mengetahui bahwa guru UPT Satuan Pendidikan SMAN 1 Jeneponto mengetahui adanya penilaian HOTS melalui berbagai sumber informasi dan berbagai tanggapan telah dijelaskan oleh informan pada proses wawancara. Pendapat yang dikemukakan informan ialah sikap setuju atau tidak setuju terhadap penerapan penilaian berorientasi HOTS. Metode dokumentasi juga tidak luput digunakan menunjang proses wawancara.

Penelitian ini berjudul Persepsi Guru Terhadap Penilaian Higher Order Thinking Skills studi pada UPT Satuan Pendidikan SMAN 1 Jeneponto. Persepsi merupakan pandangan seseorang terhadap suatu obyek yang akan menimbulkan respon tentang bagaimana seseorang dan dengan apa seseorang akan bertindak. Persepsi setiap orang tentu berbeda karena sebagai salah satu makhluk individu setiap manusia memiliki pandangan yang berbeda sesuai dengan tingkat pengetahuan dan pemahamannya. Semakin tinggi pengetahuan dan pemahaman seseorang pada obyek yang dipersepsi maka akan terbentuk persepsi yang baik pula terhadap suatu obyek. Oleh karena itu, Penelitian ini difokuskan pada (1) pengetahuan guru terhadap penilaian Higher Order Thinking Skills, (2) sikap guru terhadap penilaian Higher Order Thinking Skills.

\section{Pengetahuan Guru Terhadap Penilaian Higher Order Thinking Skills (HOTS)}

Pengetahuan adalah informasi yang dimiliki seseorang terhadap suatu obyek. Pengetahuan guru dapat ditinjau berdasarkan pada aspek pernah mengalami atau mendengar, memahami, mengaplikasikan, dan mengevaluasi penerapan penilaian HOTS. sebagai acuan, peneliti menggunakan indikator sebagai berikut: (a) Mengetahui adanya peraturan terkait penilaian Higher Order Thinking Skills. (b) Mengetahui karakteristik penilaian Higher Order Thinking Skills. (3) Mengetahui langkahLangkah penyusunan soal Higher Order Thinking Skills.

Berdasarkan indikator tersebut diatas peneliti melakukan wawancara mendalam mengenai bagaimana persepsi guru terhadap penilaian Higher Order Thinking Skills (HOTS), berikut dipaparkan hasil wawancara dengan beberapa guru UPT Satuan Pendidikan SMAN 1 Jeneponto.

\section{Mengetahui adanya peraturan tentang penilaian Higher Order Thinking Skills (HOTS)}

Seperti yang disampaikan oleh salah satu informan bernama Bapak Ismail (48 Tahun), menyampaikan bahwa: ${ }^{10}$ "Mengenai peraturan yang mengatur tentang HOTS yang saya ketahui diatur dalam peraturan menteri pendidikan dan kebudayaan, tetapi saya tidak tahu nomor berapa aturan tersebut dimuat. Saya juga belum pernah membaca aturan tersebut, bagi saya Penilaian HOTS ini masih terbilang baru, masih perlu lebih mendalami."

\section{Mengetahui karakteristik penilaian Higher Order Thinking Skills (HOTS)}

Karakteristik penilaian HOTS yang dimaksud adalah yang terdapat dalam buku penilaian berorientasi HOTS yang diterbitkan oleh Dirjen Guru dan Tenaga Kependidikan Kemendikbud

${ }^{10}$ Wawancara Tanggal 28 Juni 2019 
yang ditujukan untuk guru, yaitu karakteristik penilaian HOTS (a) mengukur kemampuan berpikir tingkat tinggi, (b) berbasis permasalahan kontekstual.

Informan memberikan berbagai pendapat berdasarkan pengalaman yang telah diperoleh. Seperti yang disampaikan oleh salah satu informan bernama Ibu Arini Astriani Azis (28 Tahun), menyampaikan bahwa:" "Saya tahu tentang penilaian HOTS melalui rapat guru oleh wakil kepala sekolah memberikan arahan agar mempelajari HOTS dan memberikan kepada peserta didik model pertanyaan dan model pembelajaran yang berorientasi HOTS. tetapi saya belum terlalu mendalami karakteristik penilaian HOTS, yang saya ketahui HOTS merupakan kemampuan berpikir secara mendalam."

\section{Mengetahui langkah-langkah penyu- sunan soal Higher Order Thinking Skilss (HOTS)}

Untuk menulis butir soal HOTS, penulis soal dituntut untuk dapat menentukan perilaku yang hendak diukur dan merumuskan materi yang akan dijadikan dasar pertanyaan (stimulus) dalam konteks tertentu sesuai dengan perilaku yang diharapkan. Selain itu uraian materi yang akan ditanyakan (yang menuntut penalaran tinggi) tidak selalu tersedia di dalam buku pelajaran. Oleh karena itu dalam penulisan soal HOTS, dibutuhkan penguasaan materi ajar, keterampilan dalam menulis soal (kontruksi soal), dan kreativitas guru dalam memilih stimulus soal sesuai dengan situasi dan kondisi daerah di sekitar satuan pendidikan.

Langkah-langkah penyusunan soal HOTS yang dimaksud peneliti yaitu (1) menganalisis kompetensi dasar yang

11 Wawancara Tanggal 26 Juni 2019

12 Wawancara Tanggal 26 Juni 2019 dapat dibuat soal-soal HOTS, (2) menyusun kisi-kisi soal, (3) memilih stimulus yang menarik dan kontekstual, (4) menulis butir pertanyaan sesuai dengan kisi-kisi soal, (5) membuat pedoman penskoran (rubrik) atau kunci jawaban. Langkah-langkah penyusunan soal HOTS tersebut menjadi acuan bagi peneliti dalam mengetahui pengetahuan guru terhadap langkah-langkah penyusunan soal HOTS.

Salah satu informan yang telah diwawancarai bernama Bapak Edy Wangsa (48 Tahun), menjelaskan bahwa:" "Langkah-langkah penulisan soal HOTS yang saya ketahui dimulai pada pemberian materi yang mengajak berpikir tingkat tinggi kepada siswa kemudian setelah itu memberikan tugas, terakhir pemberian soal-soal pada ulangan harian dan ulangan akhir semester. Terdapat pula stimulus yang sesuai dengan KD yang telah diajarkan. Rangsangan yang diberikan berupa stimulus yang dikaitkan dengan kehidupan sehari-hati atau sesuai dengan karakter lingkungan masing-masing peserta didik, misalnya salju atau kereta api yang tidak ada di Jeneponto itu tidak mungkin siswa mampu berimajinasi."

Berdasarkan penjelasan Bapak Edy Wangsa dalam wawancara diatas peneliti beranggapan bahwa informan belum terlalu mengetahui dengan jelas langkah-langkah menyusun soal HOTS. Begitu pula informan yang telah diwawancarai bernama Ibu Herawati (55 Tahun), menyatakan bahwa: ${ }^{13}$ "Saya secara pribadi tidak mengetahui sebenarnya hanya sedikit saja yang saya ketahui. saya sebenarnya jarang menerapkan HOTS pada penilaian harian karena menurut saya banyak siswa yang belum mampu menyelesaikan soal HOTS. jadi saya sendiri juga jarang membuat soal HOTS, biasanya pada

\footnotetext{
${ }^{13}$ Wawancara Tanggal 26 Juni 2019
} 
penilaian akhir semester saya bersama guru-guru yang lain buat soal kategori HOTS."

\section{Sikap Guru terhadap Penilaian Higher Order Thinking Skills (HOTS)}

Komponen persepsi yang selanjutnya adalah sikap. Penelitian ini ingin mengetahui tentang sikap guru UPT Satuan Pendidikan SMAN 1 Jeneponto yang berisi pernyataan setuju atau tidak setuju terhadap penerapan penilaian HOTS. Menurut Robbins sikap ialah pernyataan evaluatif terhadap objek, orang atau peristiwa. Sikap mencerminkan perasaan seseorang terhadap sesuatu. ${ }^{14}$ Hasil penelitian di UPTD SMAN 1 Jeneponto menunjukkan bahwa sikap guru terhadap penilaian HOTS berorientasi dalam dua ranah sikap yakni pernyataan sikap setuju dan sikap tidak setuju, yaitu sebagai berikut:

\section{Pernyataan Sikap Setuju guru terhadap penerapan penilaian Higher Order Thinking Skills (HOTS)}

Sikap setuju yang dimaksud adalah wujud persetujuan guru terhadap diterapkannya penilaian HOTS disertai alasan menyetujui penerapan penilaian HOTS. Berdasarkan wawancara mendalam yang dilakukan peneliti terhadap informan, diperoleh hasil wawancara yang disampaikan oleh salah satu informan bernama Bapak Rahman (48 Tahun) menyatakan bahwa: ${ }^{15}$ "Penilaian HOTS bukan cuma penting tetapi sangat penting untuk dilaksanakan, karena pemerintah telah menetapkan kebijakan terkait hal tersebut.. maka dengan alasan tersebut saya setuju dengan adanya penerapan penilaian HOTS. Meskipun sebenarnya ini menjadi

\footnotetext{
${ }^{14}$ Robbins, Stephen P.(2007) Perilaku

Organisasi. Jakarta: Salemba Humanika
}

tantangan tersendiri bagi guru, jadi, karena ini tantangan maka semua hambatan yang timbul harus diatasi dan tetap dilanjutkan.

Pernyataan Bapak Rahman menitikberatkan alasan persetujuannya pada penilaian HOTS yang memiliki dasar hukum sehingga sebagai guru profesional berkewajiban menjalankan tugas berdasarkan ketentuan yang berlaku.

\section{Pernyataan Sikap Tidak Setuju guru terhadap penerapan penilaian Higher Order Thinking Skills (HOTS)}

Berdasarkan hasil wawancara yang dilakukan peneliti terdapat banyak temuan sikap kontra yang dinyatakan oleh informan mengenai penerapan penilaian HOTS dengan beragam alasan yang dikemukakan. Seperti hasil wawancara yang disampaikan oleh salah satu informan bernama Ibu Nurhayati (50 Tahun) menyatakan bahwa: ${ }^{16}$ "Penilaian HOTS berdasarkan pengalaman saya setelah saya terapkan pada mata pelajaran sejarah teternyata sulit untuk dilaksanakan karena peserta didik kita itu kurang membaca sementara bentuk pertanyaannya memiliki level tingkat tinggi jadi peserta didik kesulitan untuk menjawab soal yang diberikan Itu yang jadi alasan saya tidak menyetujui penerapan penilaian HOTS terkhusus di SMAN 1 Jeneponto dan saya yakin disekolah lain juga pasti banyak guru yang sependapat dengan saya terutama sekolah-sekolah yang berada di daerah."

Sikap tidak setuju terhadap penerapan penilaian HOTS dinyatakan oleh informan dengan alasan pada mata pelajaran sejarah peserta didik kesulitan mengerjakan soal HOTS yang diberikan oleh guru karena keadaan kebanyakan

\footnotetext{
${ }^{15}$ Wawancara Tanggal 27 Juni 2019

${ }^{16}$ Wawancara Tanggal 26 Juni 2019
} 
peserta didik yang kurang membaca sementara soal yang diberikan memiliki level yang tinggi. Pernyataan informan tersebut menitik beratkan pada keadaan peserta didik yang tidak bisa menyesuaikan dengan penilaian HOTS.

Senada dengan Ibu Nurhayati (50 Tahun), salah satu informan bernama Ibu Agustini Idries (48 Tahun) menyatakan bahwa: ${ }^{17}$ "Saya tidak setuju terhadap penerapan penilaian HOTS karena peserta didik ketika diberikan soal HOTS langsung menyerah itu berarti peserta didik tidak siap jika diberikan soal HOTS, bahkan soal yang bukan HOTS saja terkadang siswa tidak mampu menjawab. Memang ada pesrta didik yang mampu menjawab tetapi kebanyakan yang saya temukan belum bisa diberikan soal HOTS. ini saya temukan di mata pelajaran yang saya ajarkan yaitu matematika. Sebelum menerapkan penilaian HOTS bukan hanya aspek guru yang ditinjau tapi harus juga disesuaikan sama keadaan peserta didik kita."

\section{Pengetahuan Guru Terhadap Penilaian Higher Oder Thinking Skill (HOTS)}

Pengetahuan merupakan hasil tahu setelah memaknai suatu obyek dengan menggunakan panca indera. Pengetahuan seseorang akan mempengaruhi persepsinya terhadap suatu obyek. Untuk dapat mengetahui pengetahuan seseorang terhadap objek yang ingin diteliti, dapat dilakukan metode wawancara atau angket yang menanyakan tentang isi materi yang ingin diukur dari informan. Berikut pembahasan dari hasil penelitian yang telah diuraikan sebelumnya terkait pengetahuan guru terhadap penilaian Higher Order Thinking Skills (HOTS):
Mengetahui adanya peraturan tentang Penilaian Higher Order Thinking Skills (HOTS)

Hasil wawancara tentang pengetahuan guru mengenai adanya peraturan tentang penilaian HOTS menunjukkan bahwa sebagian besar guru masih kurang mengetahui dengan jelas tentang peraturan tersebut. Sebagai mana uraian pada hasil penelitian salah satu informan bernama Bapak Ismail mengakui bahwa belum mengetahui dengan jelas peraturan terntang penilaian HOTS.

Berbeda halnya dengan Bapak Baharuddin yang menjelaskan bahwa penilaian HOTS diatur dalam Permendikbud No. 20 Tahun 2016 namun belum mengetahui isi dari praturan tersebut. Pada hasil penelitian informan bernama Bapak Samamang juga menjelaskan belum pernah mengikuti sosialisai terkait penilaian HOTS. Informan memperoleh informasi mengenai penilaian HOTS dari rekan sesama guru atau pada forum MGMP. Berdasarkan pengetahuannya, maka informan akan menentukan sikap setuju atau tidak setuju terhadap penerapan penilaian HOTS.

\section{Mengetahui karakteristik penilaian Higher Order Thinking Skills (HOTS) \\ Karakteristik penilaian HOTS yang dimaksud berdasarkan buku penilaian HOTS yaitu, (a) mengukur kemampuan tingkat tinggi dan (b) berbasis permasalahan kontekstual. Dari hasil penelitian, peniliti mengetahui bahwa sebagian besar guru mengetahui karakteristik HOTS. Informan menjelaskan penilaian HOTS mengukur kemampuan berpikir tingkat tinggi. Forum MGMP menjadi media guru dalam memperoleh informasi.}

${ }^{17}$ Wawancara Tanggal 26 Juni 2019 


\section{Mengetahui langkah-langkah penyusunan soal Higher Order Thinking Skills (HOTS)}

Merujuk pada hasil penelitian yang telah diuraikan sebelumnya peneliti menetapkan indikator agar memudahkan peneliti mengukur pengetahuan guru terhadap langkah-langkah penyusunan soal HOTS. indikator tersebut berdasarkan buku penilaian HOTS yang resmi dikeluarkan oleh Ditjen Guru dan Tenaga Kependidikan Kemendikbud, yaitu (1) menganalisis kompetensi dasar yang dapat dibuat soal-soal HOTS, (2) menyusun kisi-kisi soal, (3) memilih stimulus yang menarik dan kontekstual, (4) menulis butir pertanyaan sesuai dengan kisi-kisi soal, (5) membuat pedoman penskoran (rubrik) atau kunci jawaban.

Soal HOTS pada mata pelajaran sejarah karena kurang membaca. Apabila ditinjau lebih lanjut dalam mengerjakan soal HOTS membutuhkan keterampilan yang lebih kompleks dalam menyelesaikan soalnya. Pada dasarnya HOTS bukan jenis soal yang berisi pertanyaan yang mengukur dimensi pengetahuan secara faktual, konseptual, dan prosedural saja, tetapi umumnya mengukur dimensi metakognitif yang menggambarkan kemampuan menghubungkan beberapa konsep yang berbeda, mengintrapretasikan, memecahkan masalah, menemukan metode baru, berargumen, dan mengambil keputusan yang tepat. Jadi pengetahuan secara faktual, konseptual, dan prosedural menjadi penunjang dalam mengerjakan soal bermuatan HOTS yang mengukur dimensi metakognitif. Materi mata pelajaran sejarah berisi peristiwaperistiwa penting yang membutuhkan kemampuan mebaca sejarah dari berbagai sumber untuk dapat memahaminya. Bacaan tersebut akan menjadi pengetahuan awal bagi peserta didik dalam menyelesaikan soal HOTS yang mengukur dimensi metakognitif.

\section{PENUTUP}

Berdasarkan hasil penelitian mengenai "Persepsi Guru Terhadap Penilaian Higher Order Thinking Skills (HOTS) (Studi pada UPT Satuan Pendidikan SMAN 1 Jeneponto)" dapat disimpulkan bahwa: (1) Guru UPT Satuan Pendidikan SMAN 1 Jeneponto belum mengetahui dengan baik mengenai penilian Higher Order Thinking Skills (HOTS), terlihat dari pengetahuannya mengenai peraturan tentang penilaian HOTS, karakteristik penilaian HOTS, dan langkah-langkah penyusunan soal HOTS. (2) Persepsi guru UPT Satuan Pendidikan SMAN 1 Jeneponto terhadap penilaian HOTS terbagi atas dua sikap, yaitu: (1) Sikap Setuju terhadap penerapan penilaian HOTS dengan alasan; (a) Penilaian HOTS merupakan perintah undang-undang yang harus diterapkan. (b) Guru bersikap profesional terhadap tugas sebagai pendidik; (c) Penilaian HOTS bermanfaat untuk peserta didik dalam meningkatkan daya nalar dan kreatifitas; (d) Penilaian HOTS harus dibiasakan kepada peserta didik karena soal HOTS terdapat dalam ujian nasional. (2) Sikap tidak setuju terhadap penerapan penilaian HOTS dengan alasan: (a) Peserta didik kesulitan mengerjakan soal HOTS pada mata pelajaran sejarah karena kurang membaca; (b) Guru Matematika kesulitan menerapkan HOTS karena sebagian besar peserta didik langsung menyerah apabila diberikan soal HOTS; (c) Penilaian HOTS tidak cocok untuk diterapkan pada pada mata pelajaran Bahasa Inggris karena sebagian besar peserta didik belum menguasai kosakata; (d) Ketersediaan sarana dan prasarana penunjang HOTS di sekolah yang belum memadai; (e) Guru belum dibekali 
pemahaman yang cukup mengenai penerapan HOTS

Implikasi hasil penelitian ini dapat berupa dampak teoritis terhadap suatu pengembangan ilmu pengetahuan dan penerapannya secara praktis dalam pemecahan masalah penelitian. Berdasarkan hasil penelitian ini diketahui bahwa persepsi guru UPT Satuan Pendidikan SMAN 1 Jeneponto terhadap penilaian Higher Order Thinking Skills didominasi oleh sikap setuju terhadap penerapan penilaian Higher Order Thinking Skills. Maka hasil penelitian tersebut diharapkan mampu menjadi bahan evaluasi bagi pemerintah mengenai penerapan penilaian Higher Order Thinking Skills.

Berdasarkan kesimpulan diatas, penulis memberikan saran sebagai berikut: (1) Sebagai pendidik profesional, Guru harus memperdalam pengetahuan mengenai program pendidikan yang diberikan oleh lembaga penyelenggara pendidikan, terkhusus penilaian HOTS dengan rasa semangat agar dapat menerapkannya dengan baik; (2) guru lebih teliti dalam menentukan sikap terhadap penerapan HOTS dengan mempertimbangkan dampak yang ditimbulkan terhadap peserta didik; (3) pemerintah perlu menyelenggarakan pembinaan dan peningkatan kompetensi guru yang berisi kegiatan sosialisasi, pendidikan dan pelatihan guru, atau upaya lain yang dapat meningkatkan pengetahuan guru mengenai konsep penerapan HOTS; (4) untuk peneliti selanjutnya, peneliti disarankan mengembangkan penelitian kali ini dengan menambah objek penelitian dan menambah jumlah informan.

\section{DAFTAR PUSTAKA}

Bimo, W. (2006). Psikologi Sosial Suatu Pengantar. Yogyakarta: Penerbit Andi.
Buku Penilaian Berorientasi Higer Order Thinking Skill. 2018. Direktorat Jendral Guru dan Tenaga Kependidikan Kementerian Pendidikan dan Kebudayaan.

Humanika, S. (2011). Psikologi Sosial. Jakarta: Tim Penulis Fakultas Psikologi UI.

Jalaluddin, R. (n.d.). Psikologi Komunikasi. Bandung: Remaja Rosda Karya.

John Ivancevich, dkk. (2006). Perilaku dan Manajemen Organisasi. Jakarta: Erlangga.

Kurniasih, Imas, dan Sani Berlin. (2016). Ragam Pengembangan Model Pembelajaran Untuk Peningkatan Profesionalisme Guru. Jakarta: Kata Pena.

Modul Evaluasi dan Remedial Pembelajaran PKn, 2011

Nugroho, A. (2018). HOTS (Kemampuan Berpikir Tingkat Tinggi: Konsep, Pembelajaran, Penilaian, dan Soal-Soal). Jakarta: PT. Gramedia Widiasarana.

Robbins, Stephen P.(2007) Perilaku Organisasi. Jakarta: Salemba Humanika.

Sugiono. (2013). Metode Penelitian Pendidikan. Bandung: CV. ALFABETA.

UNM, T. P. (2015). Pedoman Penulisan Skripsi. Makassar: CV. Berkah Utami.

Afandi \& Sajidan(2017). Stimulasi Keterampilan Tingkat Tinggi. Solo: UNSPRESS

Dinni, H. N. (2018). HOTS Kaitannya dengan Kemampuan Literasi Matematika. PRISMA, 170.

Erni Rofiah, dkk. (2013). Penyusunan Instrumen Kemampuan Berpikir Tingkat Tinggi Fisika Pada Siswa SMP. Jurnal Pendidikan Fisika, 17. 
Kemendikbud, 2017. Modul Penyusunan Higher Order Thinking Skill (HOTS). Jakarta: Direktorat Jendral Pendidikan Dasar dan Menengah Departemen Pendidikan dan Kebudayaan

Nur Rochmah Lailly, dkk. (2015). Analisis Soal Tipe Higher Order Thinking Skill (HOTS) dalam Soal UN Kimia SMA Rayon B Tahun 2012/2013. Kaunia, 27.

Pipit Pudji Astutik. (2018). Integrasi Penguatan Pendidikan Karakter dan HOTS dalam pembelajaran tematik SD. Seminar Nasional Pendidikan Universitas Negeri Malang.

Zaenal Arifin, dkk. 2015. Analisis Instrumen Pengukur HOTS Matematika Siswa SMA. Seminar Nasional Pendidikan Matematika UNY.

Undang-Undang Republik Indonesia Nomor 14 Tahun 2005 tentang Guru dan Dosen

Undang-Undang Republik Indonesia Nomor 20 Tahun 2003 tentang Sistem Pendidikan Nasional

Peraturan Pemerintah Nomor 74 Tahun 2008 Tentang Guru

Peraturan Pemerintah RI Nomor 13 Tahun 2015 tentang Standar Nasional Pendidikan. Lembaran Negara RI Nomor 5670
Peraturan Pemerintah Nomor 19 Tahun 2005 Tentang Standar Nasional Pendidikan

Peraturan Presiden Nomor 87 Tahun 2017 Tentang Penguatan Pendidikan Karakter

Permendikbud Nomor 20 Tahun 2016 Tentang Standar Kompetensi Lulusan Pendidikan Dasar dan menengah

Permendikbud Nomor 21 Tahun 2016 Tentang Standar Isi Pendidikan Dasar dan Menengah

Permendikbud Nomor 22 Tahun 2016 Tentang Standar Proses Pendidikan Dasar dan Menengah

Permendikbud Nomor 23 Tahun 2016 Tentang Standar Penilaian Pendidikan Dasar dan Menengah

Permendikbud Nomor 24 Tahun 2016 Tentang Kompetensi Inti dan Kompetensi Dasar Pelajaran pada Kurikulum 2013 Pada Pendidikan Dasar dan Menengah

Nurrahma.'Konsep Dasar Penilaian Pembelajaran”. 4 Mei 2019. https://www.academia.edu/1687 8044/KONSEP_DASAR_PENI LAIAN_PEMBELAJARAN?au to $=$ download 